\title{
RANCANG BANGUN SISTEM INFORMASI AKADEMIK SMK NEGERI 1 DEPOK BERBASIS ANDROID DENGAN PENDEKATAN RAPID APPLICATION DEVELOPMENT
}

\author{
Ahmad Fauzi ${ }^{1}$, Eko Harli ${ }^{2}$ \\ 1,2Informatika, Fakultas Teknik dan Ilmu Komputer \\ Universitas Indraprasta PGRI Jakarta \\ ahmadfauzi.udzi@gmail.com, eko.harli@gmail.com
}

\begin{abstract}
The use of SMS-Gateway technology as an academic information system media in a school still has shortcomings in terms of the fees charged to schools. This makes the burden itself for a school that does not cooperate with the service provider of the SMS service. To overcome this, academic information systems based on mobile phones need to be developed. This study aims to build an academic information system based on the Android operating system on smartphones. Smartphone technology is the best solution now in making it easy to spread information. This study uses the Rapid Application Development method to build an Android-based academic information system called SisAkOne, by testing the software using the black box method. The results showed the use of RAD methods can be used to build information systems properly and in accordance with the functional requirements of the system.
\end{abstract}

Keywords: Mobile-Android, Rapid Application Development, Web Service

\begin{abstract}
ABSTRAK
Penggunaan teknologi SMS-Gateway sebagai media sistem informasi akademik pada sebuah sekolah masih memiliki kekurangan dari sisi biaya yang dibebankan pada sekolah. Hal tersebut menjadikan beban sendiri untuk sebuah sekolah yang tidak bekerja sama dengan operator penyedia jasa layanan SMS. Untuk mengatasi hal tersebut perlu dikembangkan sistem informasi akademik yang berbasis mobile phone. Penelitian ini bertujuan untuk membangun sistem informasi akademik berbasis sistem operasi Android pada smartphone. Teknologi smartphone merupakan solusi yang terbaik sekarang ini dalam memberikan kemudahan untuk menyebarkan informasi. Penelitian ini menggunakan metode Rapid Application Development untuk membangun sistem informasi akademik berbasis mobile android yang dinamakan SisAkOne, dengan pengujian perangkat lunak menggunakan metode black box. Hasil penelitian menunjukan penggunaan metode RAD dapat digunakan membangun sistem informasi dengan baik dan sesuai dengan kebutuhan fungsional sistem.
\end{abstract}

Kata Kunci: Mobile-Android, Rapid Application Development, Web Service

DOI: http://dx.doi.org/10.15408/jti.v12i2.10939 


\section{PENDAHULUAN}

Sejalan dengan peningkatan sektor Information and Communication Technology (ICT) di Indonesia, meningkat pula penggunaan perangkat teknologi khususnya telepon genggam pada kalangan masyarakat. Hasil laporan yang diterbitkan oleh situs wearesocial.com menunjukan bahwa $85 \%$ masyarakat Indonesia memiliki berbagai jenis tipe perangkat mobile [1]. Kemampuan menggunakan dan memanfaatkan perangkat teknologi yang baik dan bertujuan tepat, dapat menjadikan hal tersebut sebagai salah satu keunggulan dan salah satu faktor yang akan mengejar ketertinggalan sumber daya manusia Indonesia dari bangsa lain.

Dengan semakin banyaknya masyarakat Indonesia memiliki telepon genggam, terlebih sekarang bermunculan teknologi telepon pintar (smartphone) membuat semakin mudahnya kebutuhan akan informasi terpenuhi, dimana dan kapan saja. Seolah proses pengiriman informasi dapat dilakukan tanpa terikat ruang dan waktu. Ini juga yang menjadi alasan utama berkembangnya media informasi mulai dari telepon kabel, telepon seluler hingga satelit. Setiap elemen yang bersinggungan langsung dengan media atau sarana informasi ini terus meningkatkan fasilitas yang ada pada media tersebut [2].

Perkembangan teknologi ini membuat segala aspek kehidupan sekarang ini tidak lepas dari teknologi informasi, mulai dari perbankan, pertahanan, kesehatan bahkan tidak terkecuali bidang pendidikan dan pengajaran [3].

Teknologi informasi yang tepat guna juga dapat mengembangkan sebuah organisasi ataupun instansi, baik itu dari pengembangan mutu maupun layanan yang diberikan oleh instansi tersebut. Hal tersebut dikarenakan fasilitas dari sebuah media informasi dapat mengolah, memproduksi serta mengirimkan ataupun menerima segala bentuk pesan komunikasi dimana saja dan kapan saja, seolah-olah tanpa mengenal batasan ruang dan waktu [4].

Pemanfaatan teknologi informasi yang berkaitan dengan teknologi telepon genggam sudah dimulai dengan berkembangnya teknologi SMS-Gateway untuk penyebaran informasi yang cepat, tepat dan efisien [5]. Kemudian semenjak munculnya era smartphone dengan sistem operasi Android, teknologi informasi berubah haluan dengan arah yang lebih digital.

Media smartphone telah banyak memberikan manfaat pada perkembangan sistem informasi, banyak sekarang ini teknologi yang berbasis mobile digunakan untuk mengolah informasi seperti informasi rawat jalan pada sebuah rumah sakit [6], pemanfaat teknologi mobile pada bidang pemerintahan seperti melakukan pengurusan izin mendirikan bangunan (IMB) [7], pemanfaatan teknologi mobile pada penyebaran informasi budaya Indonesia [8], dan tekonologi mobile tidak luput mengenai dunia pendidikan sebagai salah satu sarana dalam menyebarkan informasi seperti dengan adanya mobile learning (m-learning) [9].

SMK Negeri 1 Depok sebagai salah satu sekolah negeri favorit di Kota Depok telah menggunakan teknologi SMS-Gateway pada sistem informasi akademik sekolah tersebut [2]. Namun penggunaan teknologi tersebut terkendala terhadap pemakaian pulsa yang berlebih. Hal ini karena setiap informasi yang diterima oleh siswa maupun orang tua siswa, beban biaya SMS ditanggung oleh sekolah sendiri.

Dengan beban tersebut maka perlu mengganti sistem informasi akademik yang ada, dengan konsep berbasis mobile phone. Hal ini bertujuan agar beban biaya tidak lagi ada pada pihak sekolah.

Penelitian terkait yang pernah dilakukan sebelumnya untuk menunjang penelitian ini telah banyak metode yang digunakan dalam membangun sistem informasi yang bermanfaat. Diantaranya adalah, perancangan sistem informasi perpustakaan menggunakan metode waterfall [10], perancangan sistem informasi alumni SMKN 1 Jenengan Ponorogo [11], sistem informasi kualitas air wilayah sungai di provinsi lampung dengan menggunakan metode Personal Extreme Programming (PXP) [12].

Penelitian ini kemudian menggabungkan beberapa temuan penelitian sebelumnya untuk mengembangkan sistem informasi akademik berbasis SMS-Gateway menjadi sistem informasi berbasi smartphone android sehingga dapat meningkatkan kualitas sistem informasi yang akurat, tepat waktu dan relevan [13]. Dengan mengimplementasikan metode Rapid Application Development. 


\section{METODOLOGI}

Metode penelitian yang digunakan pada penelitian ini terdiri atas metode penelitian deskriptif untuk proses analisis data, dan metode Rapid Application Development (RAD) untuk mengembangkan perangkat lunak.

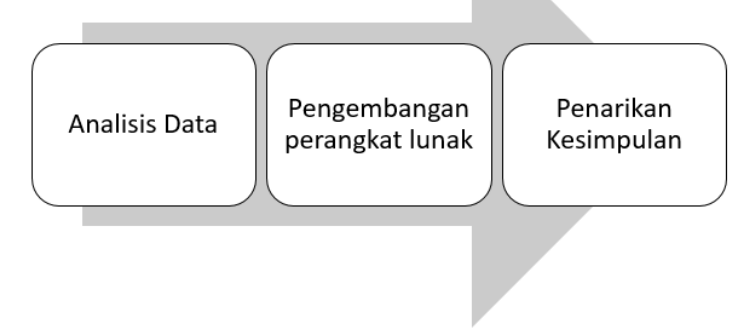

Gambar 1. Diagram blok penelitian

Secara umum, proses penelitian ini dapat dilihat pada Gambar 1. Terdapat 3 tahapan utama dalam penelitian ini yaitu 1) analisis data, 2) pengembangan perangkat lunak, 3) penarikan kesimpulan.

\section{Analisis Data}

Teknik analisis data pada penelitian ini menggunakan teknik analisis data kualitatif, hal ini berkaitan bahwa penelitian ini merupakan jenis penelitian deskriptif, dimana data yang diolah adalah data yang berwujud kata-kata bukan berupa angka [14]. Dalam mengolah data dengan teknik analisis terdapat 3 proses yaitu: 1) Reduksi Data, 2) Triangulasi Data, 3) Penarikan kesimpulan. Seperti terlihat pada Gambar 2, yaitu teknik analisis data

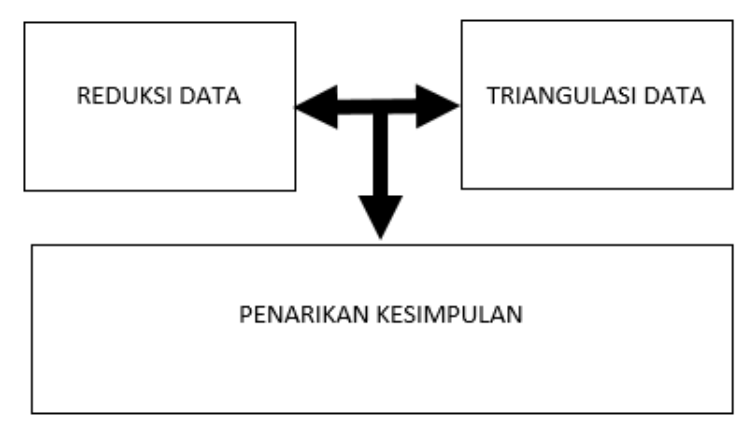

Gambar 2. Diagram teknik analisis data

Reduksi data diartikan sebagai proses pemilihan, pemusatan perhatian pada penyederhanaan, pengabstraksian, dan transformasi data kasar yang muncul dari catatan-catatan tertulis di lapangan.

Triangulasi data merupakan teknik pemeriksaan keabsahan data yang memanfaatkan sesuatu yang lain dalam membandingkan hasil wawancara terhadap objek penelitian.

Penarikan kesimpulan, dilakukan sebagai proses menyimpulkan data-data yang didapat pada proses reduksi data dan triangulasi data sebelumnya. Kesimpulan yang baik akan bergantung pada proses dan data yang didapat.

\section{Pengembangan Perangkat Lunak}

Dalam proses pengembangan perangkat lunak, penelitan ini menggunakan metode Rapid Application Development (RAD). Dengan langkah-langkah pengembangan seperti terlihat pada Gambar 3, langkah-langkah $\mathrm{RAD}$.

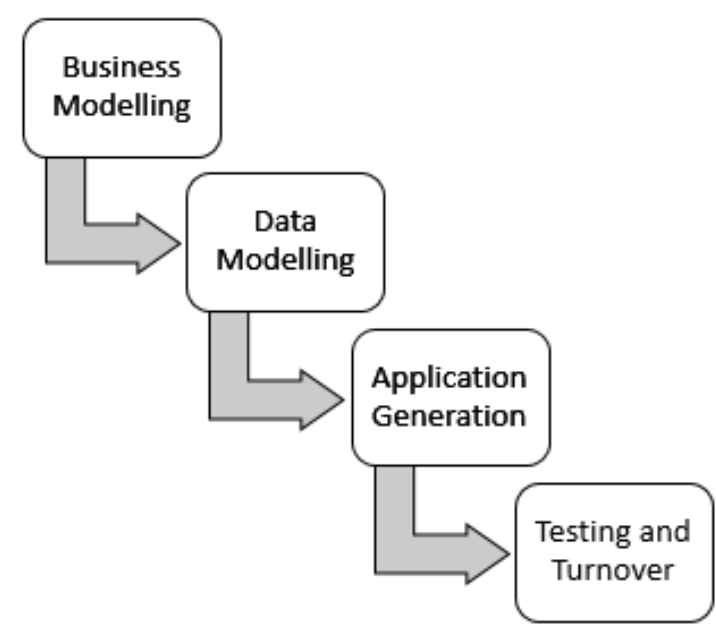

Gambar 3. Langkah-langkah RAD

Jika kebutuhan dipahami dengan baik, proses metode pengembangan perangkat lunak RAD memungkinkan tim pengembangan menciptakan "sistem fungsional yang utuh" dalam periode waktu yang sangat pendek (kirakira 60-90 hari) [15].

Pemodelan sistem yang digunakan oleh penelitian ini guna menunjang metode RAD adalah menggunakan pemodelan Unified Modeling Language (UML). UML adalah bahasa spesifikasi standar yang dipergunakan untuk mendokumentasikan, menspesifikasikan dan membangun perangkat lunak. UML merupakan metodologi dalam mengembangkan sistem berorientasi objek dan juga merupakan alat untuk mendukung pengembangan sistem [16].

Dalam Design Model System menggunakan UML, terdapat beberapa diagram yang merepresentasikan model sistem, di antaranya adalah Use Case Diagram, Activity Diagram, dan Deployment Diagram. 
3. Penarikan Kesimpulan

Proses penarikan kesimpulan, merupakan proses akhir dari keseluruhan proses penelitian. Kesimpulan didapat berdasarkan hasil akhir yang didapat dari 2 proses sebelumnya, yaitu analisis data dan pegembangan perangkat lunak.

\section{HASIL DAN PEMBAHASAN}

Dalam melakukan pengembangan sistem, metode RAD digunakan dengan pertimbangan yang baik, dimana metode ini dapat mempersingkat waktu pengerjaan dibandingkan dengan metode yang lain. Penelitian ini menerapkan langkah-langkah RAD sebagai berikut:

\section{Business Modeling}

Pada tahap ini, kebutuhan-kebutuhan dari pengguna dijelaskan secara detail dalam bentuk fungsi-fungsi yang akan dikerjakan. Kebutuhan Sistem disini adalah hal apa saja yang secara fungsional harus dapat dilakukan oleh sistem, yaitu:

a. Sistem tidak bisa diakses oleh sembarang orang kecuali terdaftar pada sekolah, hal ini menuntut sistem harus memiliki validasi login.

b. Sistem harus dapat menampilkan informasi nilai, jadwal pelajaran dan data diri untuk siswa, sesuai dengan kebutuhan siswa tersebut.

c. Sistem dapat memberikan notifikasi jika ada berita terbaru dari sekolah.

Pemodelan bisnis dalam rancang bangun sistem pada penelitian ini digambarkan pada Gambar 4, yaitu Use Case Diagram Siswa

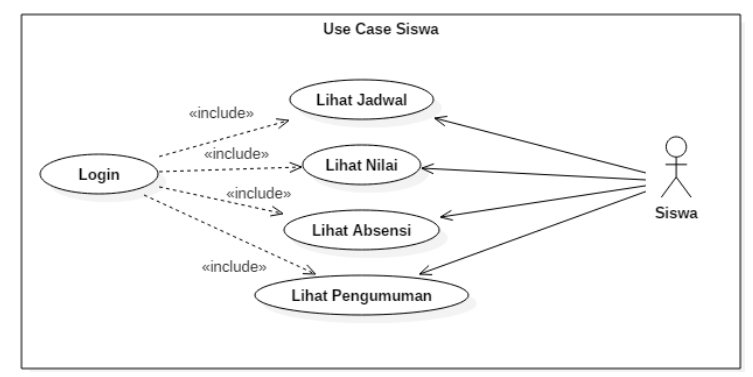

Gambar 4. Use case diagram siswa
Data modelling merupakan tahapan dimana setiap kebutuhan fungsional yang ada dipetakan kedalam bentuk pemodelan data yang merepresentasikan kedalam bentuk relational database. Penelitian ini menggunakan RDBMS MySQL sebagai database. Data yang diolah pada penelitian ini adalah:
a. Data Siswa
b. Data Kegiatan Akademik
c. Data Absensi
d. Data Pelajaran
e. Data Nilai

\section{Process Modelling}

Pada tahap Modelling Process, setiap flow bisnis yang telah ditentukan pada tahapan Business Modelling ditransformasikan ke dalam bentuk arah informasi untuk menjalankan suatu fungsi bisnis. Setiap dari hasil business modeling, akan ditransformasikan dengan menggunakan Activity Diagram

\section{Application Generation}

Pada tahapan ini, program mulai dibuat. Informasi-informasi yang telah didapatkan dari tahapan-tahapan sebelumnya digunakan sebagai acuan dalam pembuatan program.

Program yang dibuat dinamakan dengan SisAkOne, pembuatan aplikasi ini menggunakan framework native untuk smartphone yaitu ReactNative, sedangkan dalam membangun web service, penelitian ini menggunakan micro service dengan bahasa pemrograman PHP yang dibentuk dalam framework bernama Slim

\section{a. Arsitektur Sistem}

Arsitektur sistem yang dibangun, terdiri dari 3 layer, yaitu layer aplikasi, layer webservice, dan layer datasource. Arsitektur ini merupakan pengembangan arsitektur sebelumnya, yaitu dengan pengembangan teknologi SMS-gateway dengan teknologi aplikasi berbasis android.

Gambar 5 menunjukan arsitektur yang dibangun untuk aplikasi SisAkOne pada penelitian ini.

\section{Data Modelling}




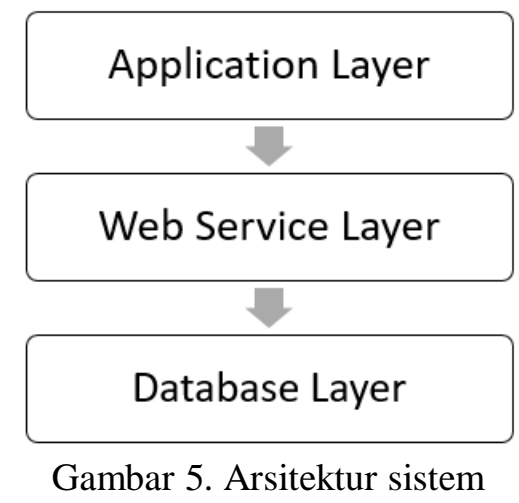

Application Layer (layer aplikasi) adalah tempat aplikasi yang berhubungan langsung dengan user, dibuat di atas platform android dengan memanfaatkan framework ReactNative. Web Service Layer, adalah sebagai penghubung antara application layer dengan database layer, dengan menggunakan JSON sebagai format pertukaran data. Database Layer adalah tempat resource yang akan diolah oleh sistem. Berupa sebuah database dengan menggunakan MySQL sebagai server database

\section{b. Arsitektur Web Service}

Seperti terlihat pada Gambar 5, yaitu Arsitektur Sistem, terdapat bagian webservice sebagai jembatan antara pengguna sistem pada perangkat mobile dengan data yang dibutuhkan disebuah cloud server. Webservice pada penelitian ini menggunakan konsep RESTFul Webservice.

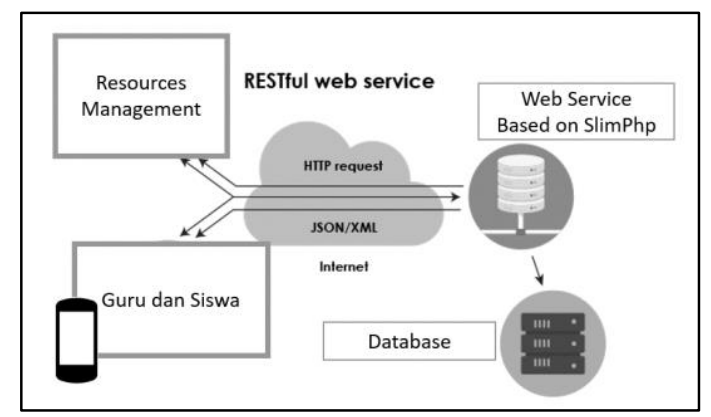

Gambar 6. Arsitektur web service

Sebuah Web Service dengan arsitektur RESTFul secara umum dapat dilihat pada Gambar 6 terdapat protokol HTTP Request yang akan me-request data kepada Web Service kemudian Web Service akan memberikan response sesuai dengan permintaan client. Untuk mempercepat performa dari Web Service, pertukaran data dilakukan menggunakan format JSON. Walaupun sebenarnya arsitektur RESTFul dapat melayani permintaan dalam format XML, namun format JSON memiliki ukuran lebih kecil dari pada XML.

\section{c. Design User Interface}

Dari arsitektur yang dibuat, kemudian menentukan rancangan layar untuk sistem yang dibangun. Khusus untuk tampilan visual (design user interface) penelitian ini berpatokan kepada 6 prinsip dasar perancangan user interface, yaitu: Layout, User Interface sebaiknya merupakan serangkaian area yang digunakan secara konsisten. Context Awareness, user harus selalu sadar/mengetahui dengan sangat baik akan posisi mereka berada. Aesthetics, User interface harus fungisonal, selain itu juga sering kali ada trade-off antara termasuk ruang putih yang cukup untuk membuat tampilan antarmuka menyenangkan User Experience, memiliki kemudahan untuk dipelajari Consistency, Konsistensi dalam desain antarmuka memungkinkan pengguna untuk memrediksi apa yang akan terjadi sebelum mereka melakukan fungsi. Minimal User Effort, user interface harus sederhana untuk digunakan.

Berikut beberapa rancangan user interface yang digunakan pada aplikasi SisAkOne:
1. Tampilan Login
2. Tampilan Menu Utama
3. Tampilan Profile Siswa
4. Tampilan Nilai Siswa
5. Tampilan Berita Akademik
6. Tampilan Jadwal Pelajaran 


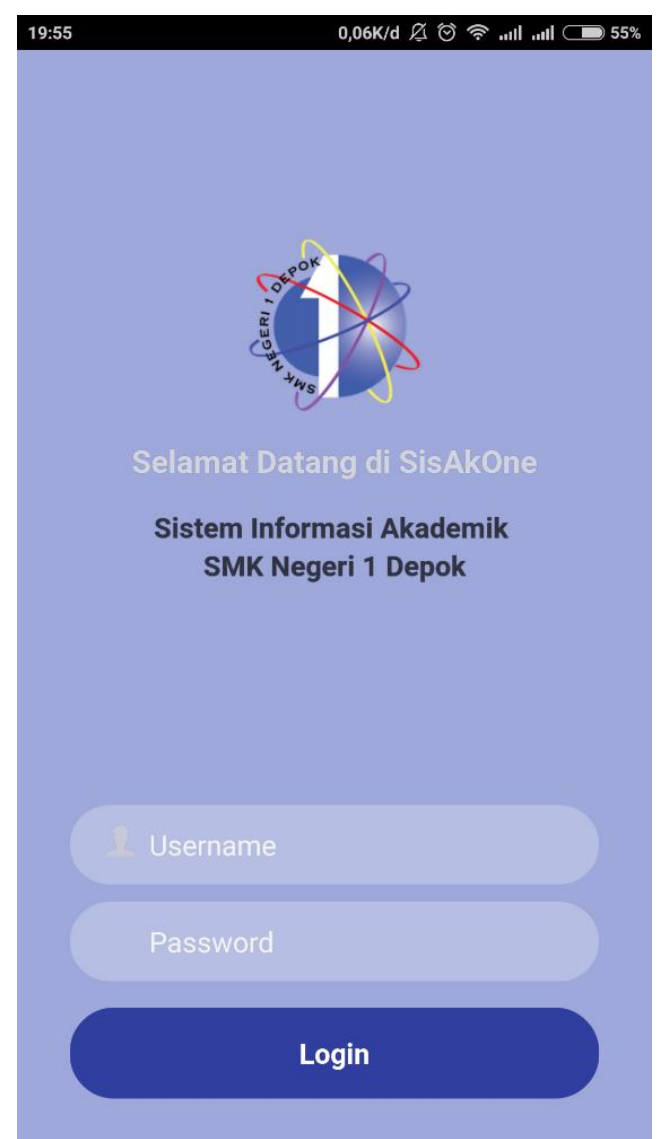

Gambar 7. Tampilan login

Gambar 7 menunjukkan tampilan login, dimana terdapat 2 input data berupa isian username dan password. Yang nantinya akan divalidasi melalui layanan WebService yang telah disediakan. Username merupakan Nomor Induk Siswa (NIS) dan password merupakan sandi yang hanya diketahui oleh siswa, dan didapatkan pada saat registrasi pertama kali.

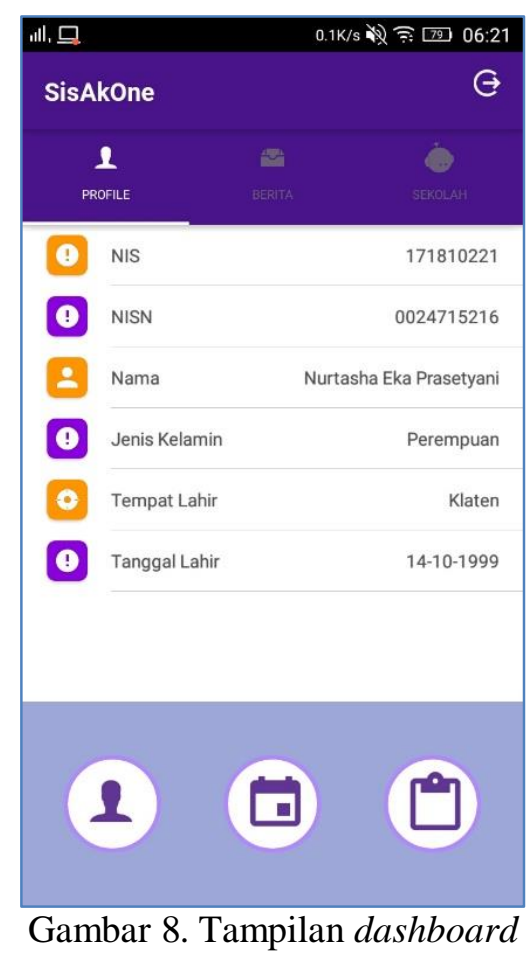

Gambar 8 menunjukkan tampilan Dashboard utama aplikasi SisAkOne. Tampilan berisi 3 pilihan menu dimana setiap menu memiliki fungsinya masing-masing sesuai tahapan business modeling. Setiap menu yang diakses hanya bisa digunakan jika pengguna sudah login terlebih dahulu, dan setiap menu menampilkan informasi berdasarkan layanan Web Service yang tersedia

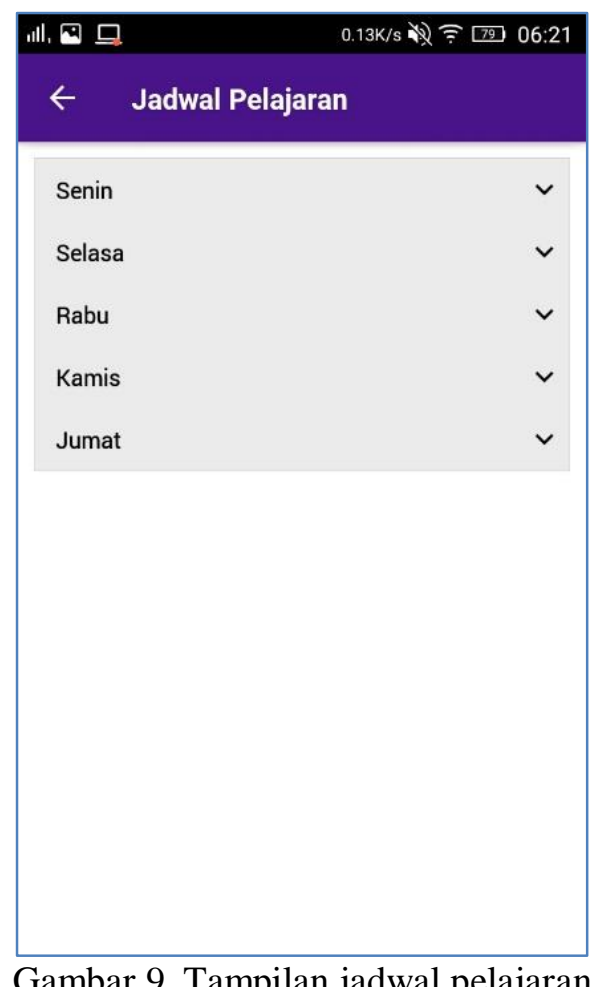

Gambar 9. Tampilan jadwal pelajaran 
Gambar 9 menunjukan tampilan jadwal pelajaran siswa berdasarkan data siswa yang login.

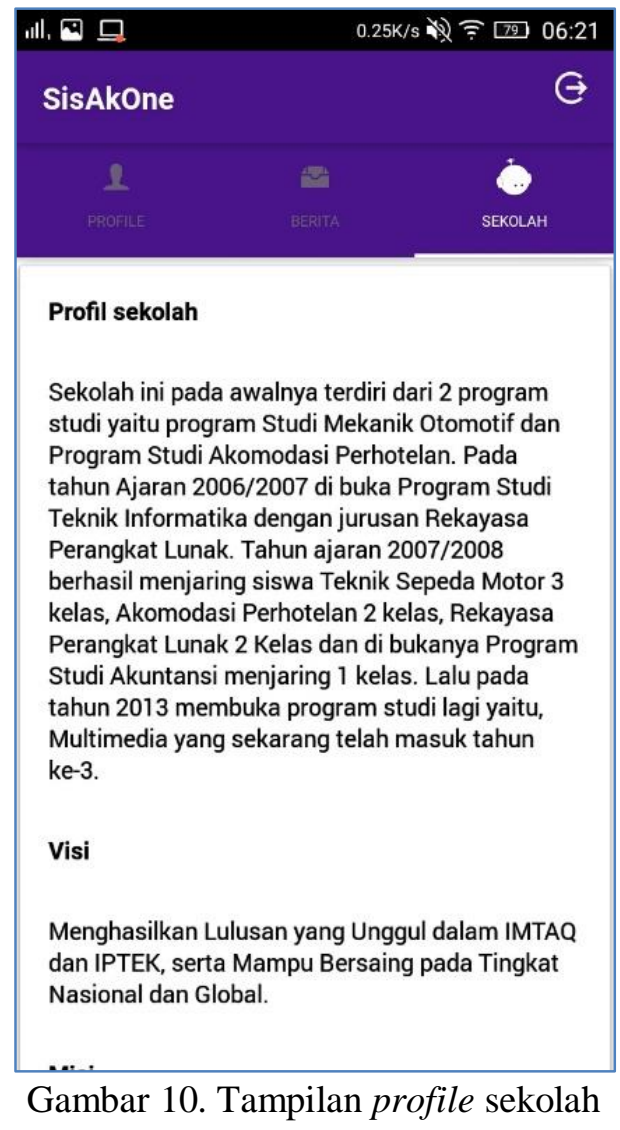

Gambar 10 menunjukan tampilan jadwal profil sekolah beserta visi dan misi.

\section{Testing}

Testing (pengujian) dilakukan terhadap prototype sistem yang telah selesai dibangun. Penggunaan metode blackbox dalam pengujian cukup untuk menggambarkan apakah kebutuhan fungsional sistem terpenuhi atau tidak [17]. Tabel 1 menyajikan hasil dari blackbox testing untuk sisi fungsionalitas sistem SisAkOne.

\section{Tabel 1. Hasil Pengujian Blackbox}

\begin{tabular}{lc}
\hline Komponen Pengujian & Hasil \\
\hline Menampilkan Halaman Login & OK \\
Login dengan data tidak valid & OK \\
Login dengan data valid & OK \\
Menampilkan Menu Utama & OK \\
Menampilkan data siswa & OK \\
Menampilkan profil siswa & OK \\
Menampilkan Nilai siswa & OK \\
Menampilkan Berita Terbaru & OK \\
\hline
\end{tabular}

\section{PENUTUP}

Teknologi yang baik dan tepat guna, dapat dirancang dan dibangun dengan metode Rapid Application Development untuk menghasilkan sebuah sistem yang perlu dibangun dengan cepat. Metode ini cukup efektif dalam membangun sistem informasi akademik berbasis android dalam penelitian ini bernama SisAkOne. Teknologi informasi berupa media smartphone secara nyata dapat memberikan informasi yang lebih cepat dan efisien. Seluruh kebutuhan sistem terpenuhi dari tahap requirements planning. Tahapan $R A D$ design memberikan fleksibelitas pada saat merancang, karena tidak terpaku hanya pada sebuah proses saja. Implementasi jadi lebih cepat karena kebutuhan pengguna yang sudah jelas. Hasil pengujian blackbox memperlihatkan bahwa sistem yang dibangun sesuai dengan kebutuhan fungsionalitas yang diperlukan SMK Negeri 1 Depok.

\section{DAFTAR PUSTAKA}

[1] https://wearesocial.com/blog/2018/01/gl obal-digital-report-2018

[2] Fauzi, Ahmad dan Harli, Eko. "Rancang Bangun Sistem Informasi Akademik Berbasis SMS Gateway dengan Metode Rapid Application Development". in University Research Colloquium (URECOL), 2017, pp. 81-86.

[3] A. Ibrahim. "Pengembangan Sistem Informasi Monitoring Tugas Akhir Berbasis Short Message Service (SMS) Gateway di Fasilkom Unsri”. Jusi. 1(2), 2011, pp. 81-92.

[4] Nurdiana, D. "Kamus Digital (InggrisIndonesia/Indonesia-Inggris) Berbasis SMS Gateway". Prosiding Seminar Program Studi Ilmu Komputer. Universitas Pendidikan Indonesia, 2009.

[5] Afrina, M. Ibrahim, A. "Pengembangan Sistem Informasi SMS Gateway Dalam Meningkatkan Layanan Komunikasi Sekitar Akademika Fakultas Ilmu Komputer Unsri”. J Sist Inf. Vol. 7. No. 2, 2015, pp. 852-64.

[6] H. Dini, et. al. "Pembangunan Sistem Informasi Rawat Jalan Berbasis Web dengan Fitur Mobile pada Puskesmas Tarok Kota Payakumbuh". Jurnal Teknologi dan Sistem Informasi 
(TEKNOSI). VOL. 03. NO. 03, 2017, pp. 353-359.

https://doi.org/10.25077/TEKNOSI.v3i3 .2017.353-359

[7] Akbar. F, et. al. "Pemanfaatan Aplikasi Web dan Mobile sebagai Penunjang Pengurusan Izin Mendirikan Bangunan Kecamatan Baso, Agam", Jurnal Teknologi dan Sistem Informasi (TEKNOSI), VOL. 04. NO. 02. 2018, pp. 073-80.

https://doi.org/10.25077/TEKNOSI.v4i2 .2018.73-80

[8] Fauzi, Ahmad. "Penerapan LocationBased Service pada Layanan Informasi Budaya Indonesia di Perangkat Mobile", Factor EXACTA jurnal ilmiah teknologi, Vol. 8, No. 3, 2015, pp. 250-260.

[9] Sarrab, Mohamed. Elgamel, Laila. Aldabbas, Hamza. Mobile Learning (MLearning) and Educational Environments. International Journal of Distributed and Parallel Systems (IJDPS) Vol.3. No.4, 2012, pp. 31-38.

[10] Lppm \& Elda Evaryanti, Luh \& Gusti Lanang Agung Raditya Putra, I \& Gede Putu Krisna Juliharta, I. Rancang Bangun Sistem Informasi Perpustakaan Berbasis Website pada SMKN 1 Gianyar. SNATIKA 2017 (ISSN:2089-1083). 04, 2017, pp. 74-80.

[11] Eka Nur Ahmad Romadhoni,Triyanna Widiyaningtyas,Utomo Pujianto. Implementasi Model Waterfall Pada Pengembangan Sistem Informasi Alumni SMKN 1 Jenangan Ponorogo. Seminar Nasional Sistem Informasi Indonesia (SESINDO), 2015.

[12] Sandika, Tri dan Kurniawan, Henry. Rancang Bangun Sistem Informasi Kualitas Air Wilayah Sungai di Provinsi Lampung dengan Metode Personal Extreme Programming. Jurnal Ilmiah ESAI. Vol. 8. No. 1, 2014.

[13] Anastasia Lipursari, 2013. Peran Sistem Informasi Manajemen (SIM) Dalam Pengambilan Keputusan. Jurnal STIE Semarang, Vol 5, No 1. pp. 26-27

[14] Moleong, Lexy J. Metodologi Penelitian Kualitatif. Bandung: PT.Remaja Rosdakarya, 2000.

[15] Kurniadi, Dede. Mulyani, Asri. Implementasi Pengembangan Student Information Terminal (S-IT) Untuk Pelayanan Akademik Mahasiswa. Jurnal
Algoritma. Vol, 13. No.1, 2016, pp. 437442.

[16] Gata, Windu dan Gata, Grace. Sukses Membangun Aplikasi Penjualan dengan Java. Jakarta: Elex Media Komputindo, 2013.

[17] Sihotang, Fransiska Prihatini; Jumeilah, Fithri Selva. Pengembangan SMS Gateway Layanan Informasi Akademik di STMIK GI MDP. Jurnal RESTI (Rekayasa Sistem dan Teknologi Informasi), Vol. 1, No. 1, 2017, pp. 58 63. ISSN 2580-0760. Available at: <http://jurnal.iaii.or.id/index.php/RESTI /article/view/12>

\section{UCAPAN TERIMA KASIH}

Apresiasi dan terima kasih kepada Direktorat Riset dan Pengabdian Masyarakat, Dirjen Penguatan Riset dan Pengembangan, Kementerian Riset, Teknologi dan Pendidikan Tinggi yang telah membiayai kegiatan Penelitian Dosen Pemula (PDP) Tahun 2018 dengan judul: "Rancang Bangun Sistem Informasi Akademik SMK Negeri 1 Depok Berbasis Android Dengan Pendekatan Rapid Application Development". Terima kasih juga kepada LLDIKTI Wilayah III Jakarta dan Lembaga Penelitian dan Pengabdian Masyarakat Universitas Indraprasta PGRI yang telah membantu kegiatan penelitian ini melalui Kontrak Penelitian: 032/K3/PNT/2018, Tanggal 6 Maret 2018. Dan Surat Perjanjian/Kontrak Penelitian UNINDRA Nomor: /SKP.LT/LPPM/UNINDRA/III/2018, Tanggal 12 Maret 2018. 